lectures, 2,513 short courses (average, 5 meetings) and 1,030 continuous classes of longer duration (average, 13 meetings). A comparison of these figures with those of the preceding six months $(29,970$ single lectures, I,785 short courses and 1,097 classes), indicates the progress of the scheme. It should be mentioned that these figures do not include lectures and classes arranged by local education authorities direct with the Services.

As one might expect, the greatest number of these lectures, etc., were given to Army units, but it is encouraging to note the increase in number of lectures to the Royal Air Force and the Navy. It is impossible to obtain accurate figures to show how much advantage is taken by the Women's Services of the regional committee facilities because there is no way of ascertaining the number of women attending in mixed audiences. But there is little doubt that the educational scheme has 'caught on' with the women auxiliaries, and this is clearly indicated by the figures set out in the report for all-women facilities.

A survey of the subjects which were discussed at these lectures and classes shows, as one might expect, the single lectures on current events are mostly in demand by the troops $(29,419$ out of a total 39,031$)$. Science lectures are divided into two categories, vocational and non-vocational, and provided 264 and 2,287 lectures respectively; psychology is listed as a separate item and accounted for 493 lectures. There were 979 single lectures on arts subjects.

As in single lectures, current affairs were much the most popular choices in the short courses $(1,664$ out of 2,420 ), but the outstanding feature here is the interest shown in short courses on music (135 out of a total of 2,420). Among the classes, languages were mostly demanded (334 out of 970) while handicrafts $(272)$ were also in favour. Vocational science classes were quite popular (131), but there was little demand for non-vocational science (12 elasses only).

Some doubts are expressed as to whether the regional committees will be able to meet the increasing demands being made upon them. But for the time being, at least, this problem seems possible of solution by the more effective use of already existing panels of lecturers. The appointment of more full-time lecturers to the regional committees would do much to ease their difficulties.

\section{CHEMICAL ATTACK UPON PESTS}

$\mathrm{I}^{\mathrm{N}}$ time of war, man becomes pest- and diseaseconscious. Under its abnormal and stringent conditions, leading to overcrowding and lack of vigilance, he, his domestic animals, his food plants, and to some extent his very elothing may become more susceptible to attack by pests and disease. War and pestilence interlock, but with increasing scientific knowledge we have ceased to regard the latter as an act of God before which we are powerless. Since the War of 1914-18, there has probably been a greater advance in the development of pest and disease control than in all past history. Much of this progress undoubtedly has been due to extensive and intensive co-operation of biologists and chemists. The early triumphs of chemotherapy gave an impetus to research outside the purely medical field, which was based upon the belief that in chemistry there existed a potential arsenal that might well be turned to account for purposes of pest control.

In a paper read before the Royal Society of Arts on March 31, Dr. R. E. Slade developed in the simplest language the story of the chemical methods now used for this purpose. Although almost any modern allotment holder knows the way, and possesses the means, of controlling many of the pests preying on his plants, a lecture of this type serves a most useful purpose in giving to the general public a co-ordinated account of a very large part of this field of research and in showing by implication how extensively and intimately it affects man's wellbeing. But surely Dr. Slade spreads his net too widely if "inconvenience to man" is to be specified as the main feature of a pest. Many birds may on occasion be an inconvenience in our gardens, but the species that rank as pests are few, and they detrimentally affect man's well-being. A dire word should surely be retained for grave ends.

It has frequently been stressed that most of the important insecticides and fungicides have keen known for many years and that chemical research has added few to their number. Dr. Slade only in part answers this challenge, and confesses that chemists are finding the replacement of certain insecticides a formidable task. Many discoveries in all branches of science and industry have been due to chance, but their systematic improvement and development have been the result of strenuous and systematic research. The discovery of derris root in 1848 by Oxley was apparently a chance one, but its introduction to the Western world by Durham was the result of scientific research, its improvement resulted from years of selection research by Georgi and his co-workers in the Department of Agriculture in Malaya, and the structure of its active principles from the labours of a number of scientifie men. Here one notes a feature which adds to the chemist's difficulties-the structural asymmetry of the insecticidal principles derived from plants, and the dependence of their very potent toxic action upon minute particulars in specific structures. The need at present, at least upon the research side, is a more intimate physiological knowledge of how these potent principles act. The co-ordination of effort between chemist, physicist and biologist, which Dr. Slade rightly stressed, needs carrying, and will be carried, a further stage.

Such a consideration is true in the fungicide field as well, but with a slightly different orientation. This field of work is closer in character to that of chemotherapy, and in the case of seed dressings and in the use of certain organic colouring matters as fungicides has at least benefited by the association.

Dr. Slade dealt only very shortly with the technical procedures used in the laboratory or the field for evaluating results. But to both of these much research has been devoted, and also to the statistical methods of analysing the data accumulated and stating their significance. It thus happens that whereas twenty-five years ago only a general personal impression of a roughly qualitative kind could be given of the relative merits of various chemical control measures, to-day, a degree of certainty which is at least as great as that obtained in the majority of biological experiments can be realized.

Dr. Slade's lecture was almost strictly impersonal in its outlook and dealt severely with facts ; history, theory and generalization being eschewed: But. such pioneers as H. E. Durham and $J$. D. 
Gimlette, connected closely with the early introduction to general use of derris root, and that far-sighted planter Gilbert Walker, who first raised pyrethrum in Kenya, do deserve to be known and to be well thought of at this time. The encouragement given to researches on pest control by the Ministry of Agriculture and the Agricultural Research Council was justly emphasized, and there is abundant evidence at the present time that other official and public bodies are now fully aware of their importance for the preservation of stored produce, and for public health; there are, too, welcome signs of increasing consultation and co-operation between those who are carrying them out.

Definite advances in the use of the simpler organic chemical compounds as fumigants, contact insecticides and seed dressings have emerged in recent years; but one may feel a sense of frustration in that such compounds as hydrocyanic acid, lead arsenate, and Bordeaux mixture have not been completely replaced by equally efficient products, completely harmless to man. Yet there is satisfaction in feeling that so many organisms which are not only pests themselves, but also in many cases carry others still more pestiferous, are by the application of scientific method gradually being brought under control.

\section{FORTHCOMING EVENTS}

(Meetings marked with an asterisk are open to the public)

Saturday, June 5

Assoctamion for SChentifyc Photography (at the Royal Institution, 21 Albemarle Street, London, W.1), at 4 p.m. - Prof. J. Yule Bogue : "Applied Photography"; Miss, K. C. Ciark : "Indirect Radiography as applied to Medical Work" ; Dr. L. Mullins: "Miscellaneous Applications of Industrial Radiography"; Mr. C. D. Ross : "The Photography of Photo-Elastic Stress Patterns"." M.

Monday, June 7

BRItish Sociat Hyatend Counciu (in the Hastings Hall, Tavistock House, Tavistock Square, London, W.C.1), at 3.30 p.m.- Extraordinary General Meeting. Reports of Enquiries on (1) "The Emotional Prostitute"; (3) "Politics and Social Biology".

ROYAI GEOGRAPHICAI SOCTETY (at Kensington Gore, London, s.W.7), at 8 p.m.-Mr. Patrick FitzGerald : "Northern Marches of Yunnan".

Tuesday, June 8

TOWN AND Country Puanning Association (at the Connaught Rooms, Gt. Queen Street, London, W.C.2) at 1 p.m.-Presentation of the Howard Memorial M.edal to Prof. L. Patrick Abercrombie.

QURKETT MicRoscopical CLCB (at the Medical Society of London, 11 Chandos Street, Cavendish Square, London, W.1), at 7.30 p.m. Prof. H. G. Jackson : "The Evolution of Terrestrial Invertebrates".

FREE GERMAN INSTTTUTE OF SCTENCE AND LEARNING (at 16 Buckland Crescent, Iondon, N.W.3), at 8 p.m. -DDr. H. S. Hopf: "Biology
or Rassenlehre? - - Considerations on a Vital subject in the Curriculum".

Wednesday, June 9

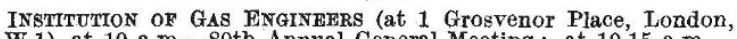
S.W.1), at 10 a.m. $\rightarrow 80$ th Annual General Meeting; at 10.15 a.m.Presidential Address by Mr. E. V. Evans.

Thursday, June 10

Town and Country Planning Assoolation (at 1 Grosyenor Place, London, S.W.1), at 1.15 p.m.-Mr. Raymond Evershed: "The Uthwatt Report".

Friday, June II

Assoclation of APPLIED Biologists (at the London School of Hygiene and Tropical Medicine, Keppel Street, London, W.C.1), at

Roysu INSTrTUTioN (at 21 Albemarle Street, London, W.1), at
5 p.m.-Dr. Bryan H. C. Matthews: "Human Limits in Flight".

\section{APPOINTMENTS VACANT}

APPLICATIONS are invited for the following appointments on or before the dates mentioned:

GRADUATE OR EQUTVALENT IN ELECTRICAL ENGINEERING, a GRaddati IN MathEMatics aND PHYsics, and a well-qualifled TEACHER OF ENGINEERING WORKSHOP PRAOTIOE AND ENGINEIERING DrawiNG, at the Bridgend Mining and Technical Institute-The Director of Education, County Hall, Cardiff (June 11).

Headmaster of THE JUNIOR Technical School of Acton TECHNICAL COLLEGE-The Secretary (T), Middlesex Education Committee, 10 Great George Street, Westminster, London, S.W.1 (June 14).

Dimonstrator (MaN OR WOMAN) IN THE PHYSICS DEPaRTMENT in London-The Warden and Secretary, London (Royal Free Hospital) (June 15)

SENIOR LECTURER IN ChEMISTRY, and a SkNIOR LEOTURFR IN PHYsics-The Clerk to the Governors, South-East Essex Technical College and School of Art, Longbridge Road, Dagenham, Essex (June 16).

LECTURER IN THE DEPARTMENT OF MECHaNIOAL ENGINERRINGLecturiar in Veriernary Pathology-The Registrar, The University, Liverpool (June 18).

PSYCHIATRIO SOCIAL WORKER (FEMALE), non-resident, to co-operate with medical staff in investigating history and social welfare of menta cases-The Medical Superintendent, Durham County Mental Hospital,
Winterton, Sedgefleld, Stockton-on-Tees (endorsed 'Social Worker') (June 19).

DIRECTOR OF THE TRANSVAAL MUSEUM, Pretoria-The Secretary, Office of the High Commissioner for the Union of South Africa, South Africa House, Trafalgar Square, London, W.C.2 (June 26).

IEOTURER IN ANIMAL HUSBANDRY at the Imperial College of Tropical Agriculture in Trinidad-The Acting Secretary, Imperia College of Tropical Agriculture, Grand Buildings, Trafalgar Square,
London, W.C.2 (June 30).

ASSISTANT ENGINEERS (4) IN THE DEPARTMENT OF POSTS AND TelegrapHS-The Secretary, Civil Service Commission, 45 Upper $0^{\prime}$ Connell Street, Dublin (July 2).

LECTURTR IN THW ENGINERING DEPARTMENT-The Registrar, Technical College, Cheltenham.

JUnior Instrumant Maker In THe SURgical Instrument ProDUCTION DEPARTMENT, Government of India-The Secretary, OverDUCTION DEPARTMENT, Government of India-The Secretary, Overseas Manpower Committee (Ref. 756), Ministry of Labour,
Service, Sardinia Street, Kingsway, London, W.C.2.

REFRAOTORInS ENGINERR (with General Engineering training and particularly experience in Refractory Work, such as Retort Setting, Coke Oven Erection and Maintenance, including the Building of Kiln Linings, Chemical Brickwork and Furnace Work)-The Ministry of Labour and National Service, Central (Technical and Scientiflc) Register (Ref. C.1647X), Alexandra House, Kingsway, London, W.C.2.

InOTuRER IN PHYsios-The Clerk to the Governors, South-West Essex Technical College and School of Art, Forest Road, Walthamstow, London, E.17.

Mastre For Chemistry-The Principal, County Secondary School and Cumberland Technical College, Workington.

JUNIOR SCIENTIYIC ASSISTANT (TEMPORARY) IN THE DEPARTMENT of Economos-The Advisory Economist, Harper Adams Agricultural College, Newport, Shropshire.

Psychiatric Socrat WORKER-The Medical Superintendent, Springfleld Mental Hospital, Tooting, London, S.W.17.

SECOND Psychiatrid SOCIAI WORKER-The Medical Superintendent, Three Counties Mental Hospital, Arlesey, Beds.

\section{REPORTS and other PUBLICATIONS (not included in the monthly Books Supplement) Great Britain and Ireland}

Fortleth Annual Report, 1942-1943, of the Imperial Cancer Research Fund. Pp. 32. (London: Imperial Cancer Research Fund.) [194 London for the Year 1942. Pp. 17. (London: Zoological Society of London.)

[194 A Plan for Education. Pp. 16. (Cheltenham: National Union of Teachers, Toddington.) 1d. [194 Institute of Welding: Welding Research Council. Memorandum on Deep Penetration Butt Welding and Semi-Automatic Welder.
(T. 10.) Pp. 4. (London: Institute of Welding.)

\section{Other Countries}

Brooklyn Botanic Garden Record. Vol. 32, No. 1: The Herb Garden of the Brooklyn Botanic Garden. Part 1: Culinary Herbs, their Culture, Traditions and Use, by Elizabeth Remsen Van Brunt; Part 2: Cooking with Herbs, by Virginia Riddle Svenson. (Guide Part 2: Cooking with Herbs, by : (Brooklyn, N.Y.: Brooklyn Institute of Arts and
No. 15.) Pp. 42. (194 Annals of the Carnegie Museum. Vol. 29, Art. 14: New and Rare Ithomiinæ (Lepidoptera) in the Carnegie Museum. By Richard M. Fox. Pp. 397-408 +1 plate. (Pittsburgh, Pa.: Carnegie Museum.) [194 U.S. Department of Agriculture. Circular No. 663: A Method of Fstimating Reduction in Yield of Wheat caused by Hessian Fly Infestation. By C. C. Hill, E. J. Udine and J. S. Pinckney. Pp. 10. (Wash-
ington, D.C.: Government Printing Office.) 5 cents.
[214 